\title{
Soil-to-mushroom transfer and diversity in total mercury content in two edible Laccaria mushrooms
}

\author{
Anna K. Kojta ${ }^{1} \cdot$ Jerzy Falandysz $^{1}$
}

Received: 22 December 2015/Accepted: 8 September 2016/Published online: 16 September 2016

(c) The Author(s) 2016. This article is published with open access at Springerlink.com

\begin{abstract}
Transfer factor and distribution of mercury were determined for Laccaria amethystina and Laccaria laccata growing in two distantly localized regions of the world and with different status of geogenic mercury. Mushrooms and soil were sampled in Poland in 2001-2013 and in the Yuxi region of Yunnan Province in China in 2013. The mushroom $L$. laccata was a more efficient accumulator of mercury than L. amethystina. Total mercury contents of whole fruiting bodies of $L$. amethystina and L. laccata at most sampling sites in Poland were low, i.e., around $0.02-0.1 \mathrm{mg} \mathrm{kg}^{-1}$ dry matter. For L. laccata from the Yuxi County of Yunnan province in China, $\mathrm{Hg}$ was at around $0.04 \mathrm{mg} \mathrm{kg}^{-1}$ dry matter. The median soil-to-mushroom transfer factors that are by some researchers also called bioconcentration factors calculated for L. amethystina were below 1 , and for L. laccata they were from 3 to 20 . The levels of contamination with mercury of both species do not pose toxicological problems, even if these species are consumed by mushroom fanciers in large amounts.
\end{abstract}

Keywords Bioconcentration · Mercury · Organic food · Wild-growing mushrooms

\section{Introduction}

Elemental mercury $(\mathrm{Hg})$ easily diffuses into air and is prone to long-range atmospheric transport (Olivero-Verbel et al. 2015; UNEP 2013). $\mathrm{Hg}\left(>95 \%\right.$ as $\left.\mathrm{Hg}^{\circ}\right)$ in ambient

Anna K. Kojta

annakojta@gmail.com

1 Laboratory of Environmental Chemistry and Ecotoxicology, Gdańsk University, 63 Wita Stwosza Str., 80-952 Gdańsk, Poland atmosphere is slowly oxidized and undergoes deposition onto land and sea surfaces. Preferential deposition of oxidized $\mathrm{Hg}$ and $\mathrm{Hg}^{\circ}$ on vegetation/air surfaces and soils was noted at higher elevations because of cloud and fog formation and high rates of rain or snow deposition (Ritchie et al. 2006; Schemenauer et al. 1995; Stankwitz et al. 2012; Zhang et al. 2013), and over time Hg accumulates in topsoil also by seasonal litterfall and throughfall (Demers et al. 2007). The process of $\mathrm{Hg}$ deposition is similar to that of persistent organic pollutants (POPs) by the "circumpolar wall" or cold condensation (Rappe 1974).

Mushrooms of different feeding strategies (saprobes, ectomycorrhizal) growing in background areas are often able to accumulate $\mathrm{Hg}$ and other metallic elements from the substratum by the live mycelium and sequester it into the fruiting bodies at high concentrations, e.g., $\mathrm{Hg}$ at much greater concentrations than other vegetation (Árvay et al. 2014; Falandysz et al. 2015a, b; Falandysz and Brzostowski 2007; Melgar et al. 2009; Nasr and Arp 2011; Saba et al. 2016; Tel et al. 2014). Hence, both edible and inedible mushrooms collected from uncontaminated areas often show $\mathrm{Hg}$ at much greater concentrations than other vegetation (Chudzyński et al. 2011; Falandysz et al. 2001a, 2013; Kojta et al. 2015; Krasińska and Falandysz 2015, 2016; Mleczek et al. 2015; Nasr et al. 2012; Rieder et al. 2011). Mushrooms with deeper mycelia in soils can absorb geogenic $\mathrm{Hg}$ at highly elevated concentrations at the sites with $\mathrm{Hg}$ geochemical anomaly due to occurrence of the global CircumPacific Mercuriferous Belt, and available examples showed that up to $4.8 \mathrm{mg} \mathrm{kg}^{-1}$ dry matter (dm) is in caps of edible Leccinum chromapes (Forst.) Sing in Yunnan, China (Falandysz et al. 2015b), up to $10 \pm 3 \mathrm{mg} \mathrm{kg}^{-1} \mathrm{dm}$ in caps of Boletus aereus in southern region of Spain and up to $13 \mathrm{mg} \mathrm{kg}^{-1} \mathrm{dm}$ in this mushroom in Yunnan or up to $23 \mathrm{mg} \mathrm{kg}^{-1} \mathrm{dm}$ in caps of Boletus edulis in Yunnan 
(Falandysz et al. 2015b, c; Ostos et al. 2015). A specific but locally important problem is occurrence of $\mathrm{Hg}$ at highly elevated concentrations in mushrooms growing in the sites more or less impacted by former $\mathrm{Hg}$ mines and smelters and other Hg deposits (Árvay et al. 2014; Kojta et al. 2015). These new data highlight a phenomenon of highly elevated concentrations of Hg noted in valuable for consumers' wildgrowing mushrooms in regions of the world and exposure of consumers. In addition, mercury accumulated in fruiting bodies is largely retained in flesh during cooking and pickling, e.g., blanching (a short-time boiling of fresh mushrooms - typically for $10 \mathrm{~min}$ ), and further is not lost in their pickling (Drewnowska 2015; Falandysz and Drewnowska 2015).

Litter, humus and soil solution are sources of minerals for mushrooms (Johanson et al. 2004). At places with elevated airborne $\mathrm{Hg}$ deposition due to long-range transport, litterfall can be a major pathway for $\mathrm{Hg}$ loading to humus and topsoil of forest catchments (Zhou et al. 2013). For mushrooms with shallow mycelia, contaminated litter seems to be a major source of Hg (Falandysz et al. 2014). This phenomenon has been well studied for radiocesium (134/137Cs) deposited from fallout onto surface of the forest floor, which is easily bioconcentrated by mushrooms with shallow mycelia such as L. amethystina (Falandysz and Borovička 2013; Falandysz et al. 2015a; Stijve and Poretti 1990).

This study is aimed at getting insight into the $\mathrm{Hg}$ accumulation by Laccaria laccata and L. amethystina collected individual foragers in Poland and elsewhere in Europe and also L. laccata widely collected across a whole China (Gumińska and Wojewoda 1985; Zhang et al. 2015; Mao 2009). Investigated was accumulation capacity of the element in the morphological parts of the fruiting bodies of L. laccata and L. amethystina and calculated were values of the $\mathrm{Hg}$ transfer factor in relation to levels in soil substrata. Also evaluated was intake of $\mathrm{Hg}$ from the L. laccata and L. amethystina by human consumers. L. amethystina and $L$. laccata are ectomycorrhizal species with shallow mycelia, which can be seen spreading in layers of decaying leafs in deciduous and coniferous forests largely in the Northern temperature zones. Both mushrooms largely depend on inorganic nutrients absorbed from litter. Both L. laccata and L. amethystina are common in Poland but are rarely foraged by individuals; in China, they are more popular and available at food markets.

\section{Materials and methods}

The Common Deceiver Laccaria laccata (Scop.) Cooke samples were collected in both Poland (several sites) and China (region of the Ligi and Jiuxi villages, near the city of

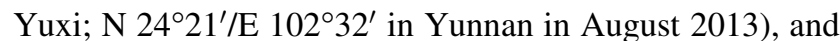
Amethyst Deceiver Laccaria amethystina (Bolt.: Hooker) MURR samples and soil substrates beneath were collected in Poland in 2001-2013 (Fig. 1). The fruiting bodies were separated into caps and stipes of which the bottom part was cut off to avoid contamination. The fungal materials and soils from certain sites were pooled to reduce costs of analyses, and each pooled sample contained from 8 to 97 specimens. The fungal materials were dried in $65^{\circ} \mathrm{C}$ to constant weight and further were pulverized in a ceramic mortar and kept in new polyethylene bags under clean and dry conditions in depository room. The soils $(0-10 \mathrm{~cm}$ layer) and litter samples free of any visible organisms, small stones, sticks and leaves were air-dried at room temperature for several weeks at free of dust conditions. Next, the soil samples were sieved through a 2-mm mesh plastic sieve and sealed in brand new polyethylene bags and kept under clean and dry conditions in depository room. Total mercury was determined using a direct sample matrices thermal decomposition and cold vapor atomic absorption spectroscopy (CV-AAS; MA-2000, Nippon Instruments Corporation, Takatsuki, Japan) (Brzostowski et al. 2011; Jarzyńska and Falandysz 2011).

The accuracy of the method was evaluated and further controlled by daily examination of fungal certified reference material (CS-M-1, dried fruiting bodies of Suillus bovinus, Institute of Nuclear Technology and Chemistry, Warsaw, Poland), with a nominal $\mathrm{Hg}$ concentration of $0.174 \pm 0.018 \mathrm{mg} \mathrm{kg}^{-1}$ dry matter $(\mathrm{dm})$, while our measurements showed $0.167 \pm 0.004(n=6$; average recovery at $96.0 \%)$ and $0.165 \pm 0.006 \mathrm{mg} \mathrm{kg}^{-1} \mathrm{dm} \quad(n=6$; average recovery at $94.8 \%$ ). For mushrooms and the soil substrates, the limit of detection was $0.0015 \mathrm{mg} \mathrm{kg}^{-1} \mathrm{dm}$, and the quantification limit was $0.005 \mathrm{mg} \mathrm{kg}^{-1} \mathrm{dm}$.

\section{Results and discussion}

\section{Content of $\mathrm{Hg}$ in mushroom bodies}

The range of values of $\mathrm{Hg}$ contents of $L$. amethystina and L. laccata of present study is listed in Table 1 . For $L$. amethystina, the $\mathrm{Hg}$ median/mean contents of caps ranged from 0.011 to $0.15 \mathrm{mg} \mathrm{kg}^{-1} \mathrm{dm}$, and for stipes the values were usually lower (quotient of $\mathrm{Hg}$ content of caps and stipes ranged from 0.80 to 4.1 ; Table 1 ). For L. laccata from Poland, a range of $\mathrm{Hg}$ contents was even wider if compared to $L$. amethystina. The lowest median/mean value of $\mathrm{Hg}$ in caps of L. laccata was $0.022 \mathrm{mg} \mathrm{kg}^{-1} \mathrm{dm}$, around 30 times more was in specimens from the Włocławek forests, which showed 0.71 and for stipes was $0.57 \mathrm{mg} \mathrm{kg}^{-1}$ there. This is unknown what could be a local source of elevated $\mathrm{Hg}$ content determined in L. laccata 


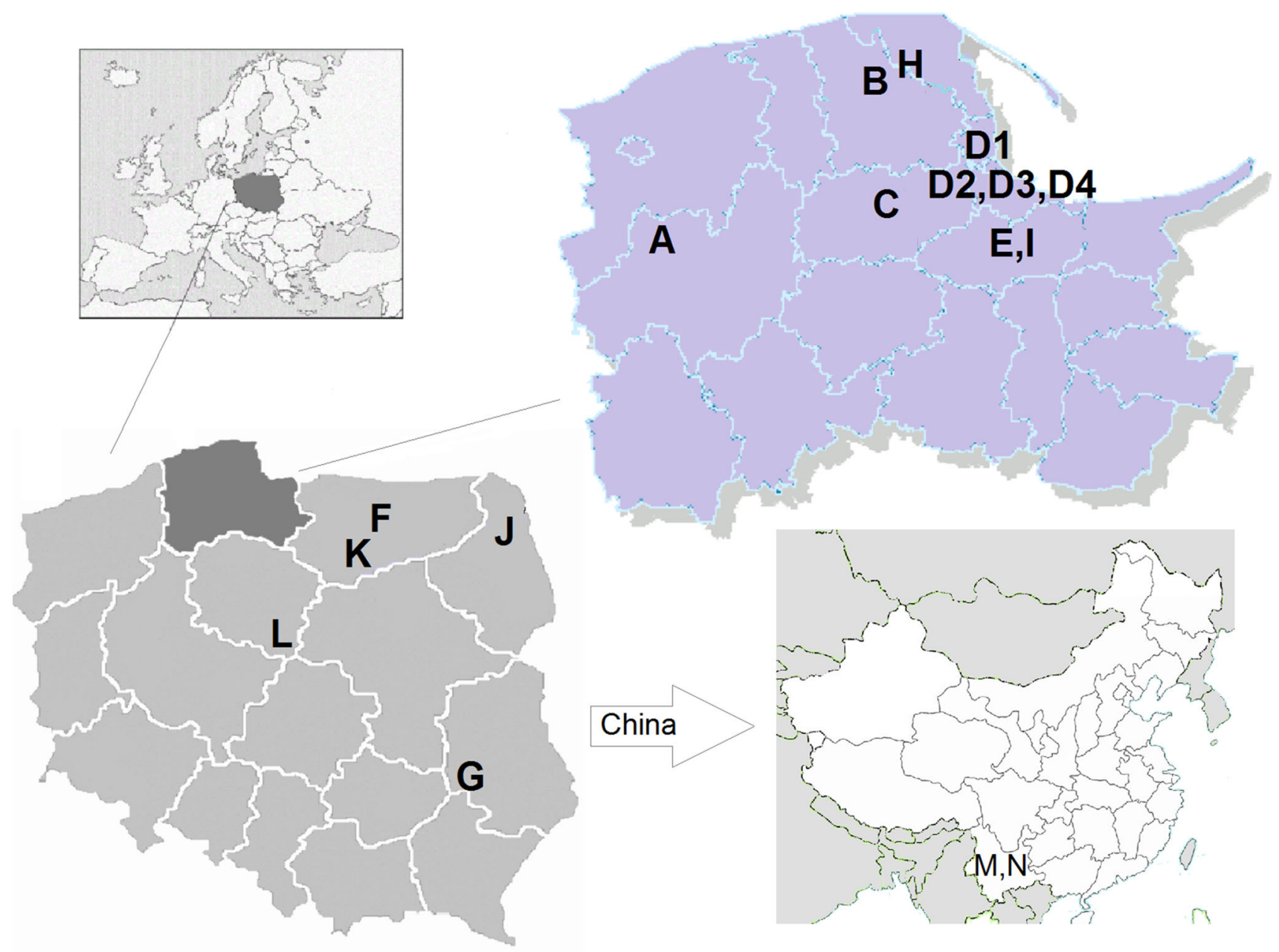

Fig. 1 Sampling sites in Poland ( $A$, Dolina Słupi Landscape Park, N $54^{\circ} 30^{\prime} / \mathrm{E} 17^{\circ} 07^{\prime} ; B$ Commune of Łacze, N $54^{\circ} 63^{\prime} / \mathrm{E} 17^{\circ} 88^{\prime}$;

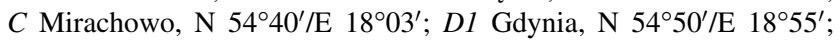

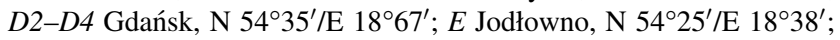
$F$ Orzechowo, N 53 $57^{\prime} / \mathrm{E} 20^{\circ} 47^{\prime}$; $G$ Poniatowa, N $51^{\circ} 83^{\prime} / \mathrm{N} 22^{\circ} 13^{\prime}$;

from the Włocławek forests. A possible explanation can be impacts from a nearby chemical industry, the Chemical Company Anwil S.A. This company was formerly known as the artificial fertilizers company: Zakłady Azotowe "Włocławek," and has been operated since 1966.

In addition to the Wloclawek site, an elevated content of $\mathrm{Hg}$ at $0.11-0.15 \mathrm{mg} \mathrm{kg}^{-1}$ also was in caps of L. amethystina sampled from the Trójmiejski Landscape Park at the Jaśkowa Dolina site, an area which has been heavily urbanized for over 100 years. Soils in the urban sites in Poland are more contaminated with $\mathrm{Hg}$ compared to background areas for which $\mathrm{Hg}$ content is $<0.05 \mathrm{mg} \mathrm{kg}^{-1} \mathrm{dm}$ (PIG 2013). In the forest ecosystem, both the litter and organic-rich surface soils can be affected by airborne $\mathrm{Hg}$ and other metallic element inputs from natural and anthropogenic, local and distant sources (Zhou et al. 2013).

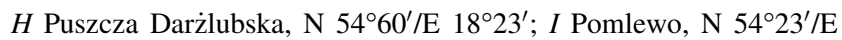
$18^{\circ} 37^{\prime}$; $J$ Puszcza Augustowska, N 52 $79^{\prime} / \mathrm{E} 23^{\circ} 43^{\prime}$; $K$ Olsztynek, N

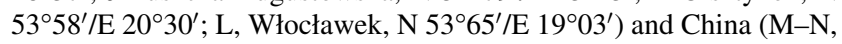
$\mathrm{N} 24^{\circ} 21^{\prime} / \mathrm{E} 102^{\circ} 32^{\prime}$ ) (symbol of the place is explained in Table 1)

The specimens of L. laccata collected from the region of County of Yuxi, Yunnan Province in China contained Hg at around 0.050 in caps and $0.030 \mathrm{mg} \mathrm{kg}^{-1}$ in stipes. Those values for L. laccata from Yunnan are similar to values determined for this species at several places in the northern part of Poland (Table 1).

There are few data published on $\mathrm{Hg}$ in L. amethystina from certain places in Europe, and one result is for $L$. laccata. In a cinnabar mining area in Tuscany (Italy), mushrooms and soil were collected and $\mathrm{Hg}$ in L. amethystina was at 0.64 and $1.0 \mathrm{mg} \mathrm{kg}^{-1} \mathrm{dm}$, while elevated was in soil beneath the fruiting bodies (4.4 and $35 \mathrm{mg} \mathrm{Hg}$ $\mathrm{kg}^{-1} \mathrm{dm}$ in $0-4 \mathrm{~cm}$ layer, while the values of $\mathrm{Hg}$ TF were low, i.e., 0.14 and 0.03) (Bargagli and Baldi 1984). For regions uncontaminated with $\mathrm{Hg}$, the data ranged for $L$. amethystina from $0.059 \pm 0.030$ to $0.067 \pm 0.005 \mathrm{mg}$ $\mathrm{Hg} \mathrm{kg}^{-1} \mathrm{dm}$ for two sites in Hungary (Vetter and Berta 
Table 1 Mean, range and median values of $\mathrm{Hg} \mathrm{mg} \mathrm{kg}^{-1} \mathrm{dm}$ content of caps and stipes of fruiting bodies of Laccaria amethystina and Laccaria laccata and beneath soil, and $\mathrm{Hg}$ cap to stipe concentration quotient $\left(Q_{\mathrm{C} / \mathrm{S}}\right)$ and $\mathrm{Hg}$ bioconcentration factor $(\mathrm{BCF})$ values

\begin{tabular}{|c|c|c|c|c|c|c|c|}
\hline \multirow[t]{3}{*}{ ID } & \multirow{3}{*}{$\begin{array}{l}\text { Place, year and number of } \\
\text { samples and specimens (in } \\
\text { parentheses) }\end{array}$} & \multicolumn{3}{|l|}{$\mathrm{Hg}$} & \multirow[t]{3}{*}{$Q_{\mathrm{C} / \mathrm{S}}$} & \multicolumn{2}{|l|}{$\mathrm{BCF}$} \\
\hline & & \multicolumn{2}{|l|}{ Fruiting bodies } & \multirow[t]{2}{*}{ Soil } & & \multicolumn{2}{|c|}{ Fruiting bodies } \\
\hline & & Caps & Stipes & & & Caps & Stipes \\
\hline \multicolumn{8}{|c|}{ Laccaria amethystina (Bolt.: Hooker) Murr. } \\
\hline A & $\begin{array}{l}\text { Pomerania, Commune } \\
\text { Dębnica Kaszubska, } \\
\text { Objezierze, Dolina Słupi } \\
\text { Landscape Park, } 2007 \\
n=15(411)^{\mathrm{a}}\end{array}$ & $\begin{array}{l}0.012 \pm 0.004 \\
0.0085-0.020 \\
0.011\end{array}$ & $\begin{array}{l}0.0098 \pm 0.0026 \\
0.0061-0.013 \\
0.0093\end{array}$ & $\begin{array}{l}0.037 \pm 0.014 \\
0.010-0.062 \\
0.018\end{array}$ & $\begin{array}{l}1.3 \pm 0.2 \\
0.77-1.6 \\
1.2\end{array}$ & $\begin{array}{l}0.39 \pm 0.24 \\
0.18-1.1 \\
0.32\end{array}$ & $\begin{array}{l}0.31 \pm 0.20 \\
0.14-0.93 \\
0.25\end{array}$ \\
\hline $\mathrm{B}$ & $\begin{array}{l}\text { Pomorskie Land, Wysokie, } \\
2006 n=6 \text { (7) }\end{array}$ & $\begin{array}{l}0.043 \pm 0.025 \\
0.019-0.081 \\
0.038\end{array}$ & $\begin{array}{l}0.019 \pm 0.006 \\
0.012-0.030 \\
0.018\end{array}$ & $\begin{array}{l}0.054 \pm 0.025 \\
0.020-0.090 \\
0.054\end{array}$ & $\begin{array}{l}2.5 \pm 2.1 \\
1.1-6.7 \\
1.8\end{array}$ & $\begin{array}{l}1.1 \pm 1.0 \\
0.21-3.1 \\
0.73\end{array}$ & $\begin{array}{l}0.52 \pm 0.49 \\
0.17-1.5 \\
0.34\end{array}$ \\
\hline $\mathrm{C}$ & $\begin{array}{l}\text { Pomerania, Mirachowo, } \\
2008 n=15 \text { (173) }\end{array}$ & $\begin{array}{l}0.023 \pm 0.013 \\
0.014-0.065 \\
0.019\end{array}$ & $\begin{array}{l}0.026 \pm 0.009 \\
0.016-0.053 \\
0.025\end{array}$ & $\begin{array}{l}0.098 \pm 0.049 \\
0.022-0.26 \\
0.12\end{array}$ & $\begin{array}{l}0.94 \pm 0.54 \\
0.30-2.5 \\
0.81\end{array}$ & $\begin{array}{l}0.28 \pm 0.25 \\
0.12-1.0 \\
0.20\end{array}$ & $\begin{array}{l}0.42 \pm 0.40 \\
0.11-1.3 \\
0.20\end{array}$ \\
\hline D1 & $\begin{array}{l}\text { Pomerania, TLP }{ }^{\mathrm{b}}, \text { Gdynia, } \\
2006 n=15 \text { (138) }\end{array}$ & $\begin{array}{l}0.015 \pm 0.002 \\
0.0092-0.017 \\
0.015\end{array}$ & $\begin{array}{l}0.010 \pm 0.001 \\
0.0077-0.012 \\
0.011\end{array}$ & $\begin{array}{l}0.090 \pm 0.044 \\
0.026-0.19 \\
0.083\end{array}$ & $\begin{array}{l}1.4 \pm 0.1 \\
1.2-1.6 \\
1.4\end{array}$ & $\begin{array}{l}0.21 \pm 0.12 \\
0.074-0.54 \\
0.19\end{array}$ & $\begin{array}{l}0.15 \pm 0.08 \\
0.048-0.34 \\
0.14\end{array}$ \\
\hline D2 & $\begin{array}{l}\text { Pomerania, TLP, Dolina } \\
\text { Radości, } 2001 n=3 \text { (15) }\end{array}$ & $\begin{array}{l}0.033 \pm 0.005 \\
0.029-0.039 \\
0.033\end{array}$ & $\begin{array}{l}0.034 \pm 0.006 \\
0.027-0.040 \\
0.036\end{array}$ & $\begin{array}{l}0.11 \pm 0.03 \\
0.064-0.16 \\
0.10\end{array}$ & $\begin{array}{l}0.99 \pm 0.22 \\
0.79-1.2 \\
0.97\end{array}$ & $\begin{array}{l}0.32 \pm 0.11 \\
0.20-0.39 \\
0.38\end{array}$ & $\begin{array}{l}0.32 \pm 0.07 \\
0.25-0.40 \\
0.31\end{array}$ \\
\hline D3 & $\begin{array}{l}\text { Pomerania, TLP, Gdańsk, } \\
\text { Jaśkowa Dolina, } 2001 \\
n=3 \text { (9) }\end{array}$ & $0.15 \pm 0.01$ & $0.11 \pm 0.02$ & ${ }^{\mathrm{c}} \mathrm{WD}$ & $1.5 \pm 0.1$ & WD & WD \\
\hline D3 & $\begin{array}{l}\text { Pomerania, TLP, Gdańsk, } \\
\text { Jaśkowa Dolina, } 2001 \\
n=1(8)^{\mathrm{d}}\end{array}$ & 0.13 & & 0.16 & WD & 0.81 & \\
\hline D3 & $\begin{array}{l}\text { Pomerania, TLP, Gdańsk, } \\
\text { Jaśkowa Dolina, } 2001 \\
n=3 \text { (12) }\end{array}$ & $\begin{array}{l}0.12 \pm 0.03 \\
0.084-0.15 \\
0.11\end{array}$ & $\begin{array}{l}0.12 \pm 0.01 \\
0.11-0.13 \\
0.12\end{array}$ & $\begin{array}{l}0.13 \pm 0.04 \\
0.065-0.16 \\
0.14\end{array}$ & $\begin{array}{l}0.80 \pm 0.21 \\
0.65-0.95 \\
0.80\end{array}$ & $\begin{array}{l}1.0 \pm 0.3 \\
0.69-1.3 \\
1.1\end{array}$ & $\begin{array}{l}1.3 \pm 0.9 \\
0.72-2.0 \\
1.3\end{array}$ \\
\hline D4 & $\begin{array}{l}\text { Pomerania, TLP, Gdańsk, } \\
\text { Niedźwiednik, } 2013 \\
n=1 \text { (97) }\end{array}$ & 0.020 & 0.011 & WD & 2.1 & WD & WD \\
\hline $\mathrm{E}$ & $\begin{array}{l}\text { Pomerania, Jodłowno, } 2013 \\
\quad n=1 \text { (91) }\end{array}$ & 0.12 & 0.029 & WD & 4.1 & WD & WD \\
\hline $\mathrm{F}$ & $\begin{array}{l}\text { Warmia Land, Orzechowo, } \\
2007 n=13 \text { (86) }\end{array}$ & $\begin{array}{l}0.017 \pm 0.002 \\
0.014-0.021 \\
0.017\end{array}$ & $\begin{array}{l}0.015 \pm 0.002 \\
0.011-0.018 \\
0.016\end{array}$ & $\begin{array}{l}0.046 \pm 0.015 \\
0.025-0.066 \\
0.043\end{array}$ & $\begin{array}{l}1.1 \pm 0.1 \\
0.96-1.5 \\
1.1\end{array}$ & $\begin{array}{l}0.40 \pm 0.13 \\
0.24-0.61 \\
0.41\end{array}$ & $\begin{array}{l}0.36 \pm 0.12 \\
0.22-0.54 \\
0.36\end{array}$ \\
\hline $\mathrm{G}$ & $\begin{array}{l}\text { Lubelskie Land, Poniatowa, } \\
\text { 1999/2001 } n=12 \text { (14) }\end{array}$ & $\begin{array}{l}0.10 \pm 0.03 \\
0.067-0.18 \\
0.095\end{array}$ & $\begin{array}{l}0.13 \pm 0.05 \\
0.079-0.21 \\
0.099\end{array}$ & $\begin{array}{l}0.11 \pm 0.02 \\
0.057-0.15 \\
0.12\end{array}$ & $\begin{array}{l}0.90 \pm 0.48 \\
0.48-2.3 \\
0.81\end{array}$ & $\begin{array}{l}0.91 \pm 0.28 \\
0.60-1.5 \\
0.85\end{array}$ & $\begin{array}{l}1.1 \pm 0.42 \\
0.66-2.0 \\
1.0\end{array}$ \\
\hline Lac & ria laccata (Scop.) Cooke & & & & & & \\
\hline $\mathrm{H}$ & $\begin{array}{l}\text { Pomerania, Puszcza } \\
\text { Darżlubska, } 2003 n=15 \\
\text { (191) }\end{array}$ & $\begin{array}{l}0.078 \pm 0.017 \\
0.051-0.11 \\
0.076\end{array}$ & $\begin{array}{l}0.066 \pm 0.017 \\
0.041-0.11 \\
0.065\end{array}$ & $\begin{array}{l}0.018 \pm 0.001 \\
0.016-0.019 \\
0.018\end{array}$ & $\begin{array}{l}1.2 \pm 0.2 \\
0.96-1.4 \\
1.1\end{array}$ & $\begin{array}{l}4.4 \pm 1.0 \\
2.7-6.4 \\
4.2\end{array}$ & $\begin{array}{l}3.8 \pm 1.0 \\
2.1-6.1 \\
3.6\end{array}$ \\
\hline $\mathrm{C}$ & $\begin{array}{l}\text { Pomerania, Mirachowo, } \\
2008 n=1 \text { ( } 29)\end{array}$ & 0.17 & 0.12 & 0.19 & 1.4 & 0.89 & 0.63 \\
\hline I & $\begin{array}{l}\text { Pomerania, Pomlewo, } 2013 \\
\quad n=1 \text { (20) }\end{array}$ & 0.030 & 0.019 & WD & 1.6 & WD & WD \\
\hline
\end{tabular}


Table 1 continued

\begin{tabular}{|c|c|c|c|c|c|c|c|}
\hline \multirow[t]{3}{*}{ ID } & \multirow{3}{*}{$\begin{array}{l}\text { Place, year and number of } \\
\text { samples and specimens (in } \\
\text { parentheses) }\end{array}$} & \multicolumn{3}{|l|}{$\mathrm{Hg}$} & \multirow[t]{3}{*}{$Q_{\mathrm{C} / \mathrm{S}}$} & \multirow{2}{*}{\multicolumn{2}{|c|}{$\frac{\mathrm{BCF}}{\text { Fruiting bodies }}$}} \\
\hline & & \multicolumn{2}{|c|}{ Fruiting bodies } & \multirow[t]{2}{*}{ Soil } & & & \\
\hline & & Caps & Stipes & & & Caps & Stipes \\
\hline \multirow[t]{3}{*}{$\mathrm{J}$} & \multirow{3}{*}{$\begin{array}{l}\text { Augustów Land, Puszcza } \\
\text { Augustowska, } 2006 \\
n=7 \text { (9) }\end{array}$} & $0.12 \pm 0.12$ & $0.11 \pm 0.13$ & $0.031 \pm 0.018$ & $1.2 \pm 0.3$ & $6.2 \pm 9.6$ & $5.9 \pm 9.1$ \\
\hline & & $0.041-0.37$ & $0.026-0.37$ & $0.011-0.051$ & $0.75-1.6$ & $0.83-28$ & $1.0-27$ \\
\hline & & 0.056 & 0.051 & 0.034 & 1.2 & 2.9 & 2.0 \\
\hline $\mathrm{K}$ & $\begin{array}{l}\text { Warmia land, Olsztynek, } \\
2003 n=1 \text { (15) }\end{array}$ & 0.022 & 0.025 & WD & 0.88 & WD & WD \\
\hline $\mathrm{L}$ & $\begin{array}{r}\text { Kujawy Land, Włocławek } \\
\text { forests, } 2006 n=1 \text { (96) }\end{array}$ & 0.71 & 0.57 & 0.074 & 1.2 & 9.6 & 7.7 \\
\hline M & $\begin{array}{l}\text { Ligi, Yuxi, Yunnan, China, } \\
2013 n=1 \text { (56) }\end{array}$ & 0.054 & 0.029 & WD & 1.9 & WD & WD \\
\hline $\mathrm{N}$ & $\begin{array}{l}\text { Jiuxi, Yuxi, Yunnan, China, } \\
2013 n=1 \text { (71) }\end{array}$ & 0.047 & 0.033 & WD & 1.4 & WD & WD \\
\hline
\end{tabular}

${ }^{a}$ Pooled samples (number of specimens in parentheses)

b TLP (Trójmiejski Landscape Park)

${ }^{c}$ WD (without data)

${ }^{\mathrm{d}}$ Pooled sample (if one pooled sample was made per place, it was examined in triplicate and the result is the mean value)

$1997)$ and between $0.10(0.08-0.11) \mathrm{mg} \mathrm{kg}^{-1} \mathrm{dm}(n=6)$ for a site in Germany (Seeger and Nützel 1976) and $0.74 \pm 0.26 \mathrm{mg} \mathrm{kg}^{-1} \mathrm{dm}$ in Turkey (Sesli and Tüzen 1999), while not provided was information on $\mathrm{Hg}$ content in soil substratum or values of TF.

The fruiting bodies of both species are edible, but their caps and stipes are small in size. Hence, the value of using the mushrooms for dietary purposes depends on dietary habit and is relatively low in Poland while they are more popular in Yunnan of China. In Poland, both L. amethystina and $L$. laccata are only sporadically collected by mushroomers. The values of $\mathrm{Hg}$ contents determined for L. amethystina and $L$. laccata for majority of the places in Poland were small, i.e., around $0.002-0.19 \mathrm{mg} \mathrm{kg}^{-1}$ if calculated for whole fruiting bodies on a fresh product basis (assuming moisture content at $90 \%$ ) (Zielińska et al. 2008; Falandysz et al. 2001b). Hence, the levels of contamination with $\mathrm{Hg}$ of both species do not possess a toxicological problem even if eaten occasionally by fanciers at greater volume or used as spices. Total $\mathrm{Hg}$ content of fresh whole fruiting bodies of L. laccata collected in the region of the city of Yuxi in the Yunnan province is around $0.004 \mathrm{mg} \mathrm{kg}^{-1}$, which is also small value when compared to many other species of edible wild-grown mushrooms that are usually much more contaminated (Falandysz et al. 2007; Drewnowska et al. 2014; Gucia et al. 2012; Kojta et al. 2012).

\section{The comparison of $\mathrm{Hg}$ content in analyzed species}

The mushrooms L. amethystina and L. laccata and soils were collected from several distantly distributed sites, while both species were available for study only from the Mirachowo site. Content of $\mathrm{Hg}$ in caps and stipes of L. laccata at the Mirachowo place was at 0.17 and $0.12 \mathrm{mg} \mathrm{kg}^{-1} \mathrm{dm}$, respectively, and was several times greater compared to 0.019 and $0.025 \mathrm{mg} \mathrm{kg}^{-1} \mathrm{dm}$, respectively, for $L$. amethystina from this site. This discrepancy in $\mathrm{Hg}$ load between two species of mushrooms with similar feeding strategy and having shallow mycelia could be attributed to genetic features and availability of ligands to sequester $\mathrm{Hg}$ in fruiting bodies but less to environmental factors, which seem largely the same for both species.

The village of Mirachowo is inhabited by around eight hundred people and is surrounded by the large complex of Mirachowskie forests, which is part of the Kaszuby Landscape Park in the northwestern region of Poland (Fig. 1). There is no local industrial activity in the village of Mirachowo, while combustion of wood and less of hard coal seems to be a solely local source of $\mathrm{Hg}$ release into the atmosphere. Deposition of airborne $\mathrm{Hg}$ due to a long-range transport from the spatially distant sources is also possible, but rates are unknown for this area. Contents of $\mathrm{Hg}$ in surface layer of soils beneath the fruiting bodies for L. amethystina and L. laccata at this site were similar, i.e., 0.12 and $0.19 \mathrm{mg} \mathrm{kg}^{-1} \mathrm{dm}$ (Table 1), while no litter was available for examination. Nevertheless, further study including collections of species litter, humus and mineral layer of soils from a several sites could give a deeper insight why both mushrooms differ in efficiency of $\mathrm{Hg}$ bioconcentration.

Soil-to-mushroom transfer factor (TF) is a value of quotient of $\mathrm{Hg}$ content of mushroom and soil. The median values of $\mathrm{Hg} \mathrm{TF}$ for $L$. amethystina were usually below 
unity and for $L$. laccata were higher, i.e., from 3 to 20 , so the mushroom $L$. laccata is more efficient accumulator than $L$. amethystina (Table 1). This observation seems to support suggestion that $L$. laccata compared to $L$. amethystina could be more abundant in transporter genes and/or ligands are able to sequester $\mathrm{Hg}$ in fruiting bodies but evidence is lacking.

Some authors suggested that L. amethystina is species which can be suitable as indicator (early indicator) of an radioactive cesium $\left({ }^{134 / 137} \mathrm{Cs}\right)$ fallout (Byrne 1988; Stijve and Poretti 1990). This is because a shallow mycelia of $L$. amethystina, despite a moderate content of the stable $\left({ }^{133-}\right.$ Cs) in fruiting bodies, allows for rapid uptake of the airborne ${ }^{134 / 137} \mathrm{Cs}$ deposited on the forest floor through litterfall and throughfall. The mushroom L. amethystina is also known because of a high content of arsenic (As) that largely occurs in its fruiting bodies in the form of dimethylarsinic acid (Larsen et al. 1998; Zhang et al. 2015). This species when growing in soil contaminated with arsenic pentoxide (500-800 mg As kg ${ }^{-1}$ at a hot spot) accumulated in flesh total As at $1420 \mathrm{~m} \mathrm{~kg}^{-1} \mathrm{dm}$ and largely biosynthesized in form of dimethylarsinic acid (68\%) (Larsen et al. 1998).

\section{Conclusions}

The results obtained in the study showed that mushroom $L$. laccata is a more efficient accumulator of $\mathrm{Hg}$ (calculated median values of transfer factor were from 3 to 20) than $L$. amethystina (values of the transfer factor are below 1). Mercury contents of whole fruiting bodies of $L$. amethystina and L. laccata for majority of the places in Poland were around 0.002 and $0.01 \mathrm{mg} \mathrm{kg}^{-1}$ fresh product, whereas for L. laccata from the Yuxi County of the Yunnan province in China was around $0.004 \mathrm{mg} \mathrm{kg}^{-1}$ fresh product. The levels of contamination with $\mathrm{Hg}$ of both species do not possess a toxicological problem even if eaten occasionally by fanciers at greater volume or used as spices.

The median values of $\mathrm{Hg} \mathrm{TF}$ for $L$. amethystina were usually below unity and for L. laccata were higher, i.e., from 3 to 20 , so the mushroom L. laccata is more efficient accumulator than $L$. amethystina.

Acknowledgments Technical support by Anna Chilicka, Dorota Chojnacka, Anna Dryżałowska, Aneta Jędrusiak, Aleksandra Konkel, Ewa Łukaszewicz, Aleksandra Mostrąg, Damroka Reglinska, Monika Szlosowska, Agnieszka Zając and Marta Zielińska is acknowledged.

\section{Compliance with ethical standards}

Conflict of interest The authors declare that they have no conflict of interest.
Ethical approval This article does not contain any studies with human participants or animals performed by any of the authors.

Informed consent Informed consent was obtained from all individual participants included in the study.

Open Access This article is distributed under the terms of the Creative Commons Attribution 4.0 International License (http://crea tivecommons.org/licenses/by/4.0/), which permits unrestricted use, distribution, and reproduction in any medium, provided you give appropriate credit to the original author(s) and the source, provide a link to the Creative Commons license, and indicate if changes were made.

\section{References}

Árvay J, Tomáša J, Hauptvogl M, Kopernická M, Kováčik A, Bajčan D, Massányi P (2014) Contamination of wild-grown edible mushrooms by heavy metals in a former mercury-mining area. J Environ Sci Health, Part B 49:815-827

Bargagli R, Baldi F (1984) Mercury and methyl mercury in higher fungi and their relation with substrata in a cinnabar mining area. Chemosphere 13:1059-1071

Brzostowski A, Falandysz J, Jarzyńska G, Zhang D (2011) Bioconcentration potential of metallic elements by Poison Pax (Paxillus involutus) mushroom. J Environ Sci Health, Part A 46:378-393

Byrne AR (1988) Radioactivity in fungi in Slovenia, Yugoslavia, following the Chernobyl accident. J Environ Radioact 6:177-183

Chudzyński K, Jarzyńska G, Stefańska A, Falandysz J (2011) Mercury content and bio-concentration potential of Slippery Jack, Suillus luteus, mushroom. Food Chem 125:986-990

Demers JD, Driscoll CT, Fahey TJ, Yavitt JB (2007) Mercury cycling in litter and soil in different forest types in the Adirondack region, New York, USA. Ecol Appl 17:1341-1351

Drewnowska M (2015) Badanie składu mineralnego wybranych gatunków grzybów jadalnych $\mathrm{z}$ rodziny muchomorowatych (Amanitaceae) i pieprznikowatych (Cantharellaceae): aspekt żywieniowy i środowiskowy. Dissertation, University of Gdańsk

Drewnowska M, Nnorom IC, Falandysz J (2014) Mercury in the Tawny Grisette, Amanita vaginata Fr. and soil below the fruiting bodies. J Environ Sci Health, Part B 49:521-526

Falandysz J, Borovička J (2013) Macro and trace mineral constituents and radionuclides in mushrooms - health benefits and risks. Appl Microbiol Biotechnol 97:477-501

Falandysz J, Brzostowski A (2007) Mercury and its bioconcentration factors in Poison Pax (Paxillus involutus) from various sites in Poland. J Environ Sci Health, Part A 42:1095-1100

Falandysz J, Drewnowska M (2015) Distribution of mercury in Amanita fulva (Schaeff.) Secr. mushrooms: accumulation, loss in cooking and dietary intake. Ecotoxicol Environ Saf 115:49-54

Falandysz J, Gucia M, Frankowska A, Kawano M, Skwarzec B (2001a) Total mercury in wild mushrooms and underlying soil substrate from the city of Umeå and its surroundings, Sweden. Ecotoxicol Environ Saf 67:763-770

Falandysz J, Szymczyk K, Ichihashi H, Bielawski L, Gucia M, Frankowska A, Yamasaki S-I (2001b) ICP/MS and ICP/AES elemental analysis (38 elements) of edible wild mushrooms growing in Poland. Food Addit Contam A 18:503-513

Falandysz J, Lipka K, Mazur A (2007) Mercury and its bioconcentration factors in Fly Agaric (Amanita muscaria) from spatially distant sites in Poland. J Environ Sci Health, Part A 42:1625-1630

Falandysz J, Mazur A, Drewnowska M, Kojta AK, Jarzyńska G, Dryżałowska A, Nnorom IC (2013) Mercury in fruiting bodies of 
dark honey fungus (Armillaria solidipes) and beneath substratum soils collected from spatially distant areas. J Sci Food Agric 93:853-858

Falandysz J, Dryżałowska A, Saba M, Wang J, Zhang D (2014) Mercury in the Fairy-ring of Gymnopus erythropus (Pers.) and Marasmius dryophilus (Bull.) P. Karst. mushrooms from the Gongga Mountain, Eastern Tibetan Plateau. Ecotoxicol Environ Saf 104:18-22

Falandysz J, Zalewska T, Krasińska G, Apanel A, Wang Y, Pankavec $S$ (2015a) Evaluation of the radioactive contamination in fungi genus Boletus in the region of Europe and Yunnan Province in China. Appl Microbiol Biotechnol 99:8217-8224

Falandysz J, Zhang J, Wang Y, Krasińska G, Kojta A, Saba M, Shen T, Li T, Liu H (2015b) Evaluation of the mercury contamination in mushrooms of genus Leccinum from two different regions of the world: accumulation, distribution and probable dietary intake. Sci Total Environ 537:470-478

Falandysz J, Zhang J, Wang Y, Saba M, Krasińska G, Wiejak A, Li T $(2015 \mathrm{c})$ Evaluation of the mercury contamination in fungi genus Boletus from the latosols and lateritic red earths and red and yellow earths in region of the Circum-Pacific Mercuriferous Belt in southwestern China. PLoS ONE. doi:10.1371/journal.pone. 0143608

Gucia M, Jarzyńska G, Rafał M, Roszak M, Kojta AK, Osiej I, Falandysz J (2012) Multivariate analysis of mineral constituents of edible Parasol Mushroom (Macrolepiota procera) and soils beneath fruiting bodies collected from Northern Poland. Environ Sci Pollut Res 19:416-431

Gumińska B, Wojewoda W (1985) Grzyby i ich oznaczanie [Mushrooms and their identification]. PWRiL, Warszawa

Jarzyńska G, Falandysz J (2011) The determination of mercury in mushrooms by CV-AAS and ICP-AES techniques. J Environ Sci Health A 46:569-573

Johanson KJ, Nikolova I, Andy FS, Taylor AFS, Vinichuk MM (2004) Uptake of elements by fungi in the Forsmark area. Technical Report TR-04-26. Svensk Kärnbränslehantering AB Swedish Nuclear Fuel and Waste Management Co, Stockholm

Kojta AK, Jarzyńska G, Falandysz J (2012) Mineral composition and heavy metals accumulation capacity of Bay Bolete's (Xerocomus badius) fruiting bodies collected near a former gold and copper mining area. J Geochem Explor 121:76-82

Kojta AK, Zhang J, Wang Y, Li T, Saba M, Falandysz J (2015) Mercury contamination of fungi genus Xerocomus in the Yunnan Province in China and the region of Europe. J Environ Sci Health, Part A 50:1342-1350

Krasińska G, Falandysz J (2015) Mercury in Hazel Bolete Leccinum griseum and soil substratum: distribution, bioconcentration and probable dietary exposure. J Environ Sci Health, Part A 50:1259-1264

Krasińska G, Falandysz J (2016) Mercury in orange Birch Bolete Leccinum versipelle and soil substratum: bio-concentration by mushroom and probable dietary intake by consumers. Environ Sci Pollut Res 23:860-869

Larsen EH, Hansen M, Gössler W (1998) Speciation and health risk considerations of arsenic in the edible mushroom Laccaria amethystina collected from contaminated and uncontaminated locations. Appl Organomet Chem 12:285-291

Mao X (2009) Macromycetes of China. Science Press, Beijing

Melgar MJ, Alonso J, Garcia MÁ (2009) Mercury in edible mushrooms and soil: bioconcentration factors and toxicological risk. Sci Total Environ 407:5328-5334

Mleczek M, Siwulski M, Mikołajczak P, Gasiecka M, Sobieralski K, Szymańczyk M, Goliński P (2015) Content of selected elements in Boletus badius fruiting bodies growing in extremely polluted wastes. J Environ Sci Health, Part A 50:767-775
Nasr N, Arp PA (2011) Hg concentrations and accumulations in fungal fruiting bodies, as influenced by forest soil substrates and moss carpets. Appl Geochem 26:1905-1917

Nasr N, Malloch DW, Arp PA (2012) Quantifying Hg within ectomycorrhizal fruiting bodies, from emergence to senescence. Fungal Biol 116:1163-1177

Olivero-Verbel J, Cabarello-Gallardo K, Turizo-Tapia A (2015) Mercury in the gold mining district of San Martin de Loba, South of Bolivar (Colombia). Environ Sci Pollut Res 22:589-5907

Ostos C, Perez-Rodriguez F, Arroyo BM, Moreno-Rojas R (2015) Study of mercury content in wild edible mushrooms and its contribution to the Provisional Tolerable Weekly Intake in Spain. J Food Compos Anal 37:136-142

PIG (2013) Geochemical mapping in Poland. http://www.mapgeo chem.pgi.gov.pl/poland/index.html. Accessed Nov 2014

Rappe C (1974) Chemical behavior of pesticides. In: Bylund E, Linderholm $\mathrm{H}$, Rune $\mathrm{O}$ (eds) Ecological problems of the circumpolar area. Norrbottens Museum, Lulea, pp 29-32

Rieder SR, Brunner I, Horvat M, Jacobs A, Frey B (2011) Accumulation of mercury and methylmercury by mushrooms and earthworms from forest soils. Environ Pollut 159:2861-2869

Ritchie CD, Richards W, Arp PA (2006) Mercury in fog on the Bay of Fundy (Canada). Atmos Environ 40:6321-6328

Saba M, Falandysz J, Nnorom IC (2016) Accumulation and distribution of mercury in fruiting bodies by fungus Suillus luteus foraged in Poland, Belarus and Sweden. Environ Sci Pollut Res 23:2749-2757

Schemenauer RS, Banic CM, Urquizo N (1995) High elevation fog and precipitation chemistry in Southern Quebec, Canada. Atmos Environ 29:2235-2252

Seeger R, Nützel R (1976) Quecksilbergehalt der Pilze. Z Lebensm Unters For 160:303-312

Sesli E, Tüzen M (1999) Levels of trace elements in the fruiting bodies of macrofungi growing in the East Black Sea region of Turkey. Food Chem 65:453-460

Stankwitz C, Kaste JM, Friedlands A (2012) Threshold increases in soil lead and mercury from tropospheric deposition across an elevational gradient. Environ Sci Technol 46:8061-8068

Stijve T, Poretti M (1990) Radiocesium levels in wild-growing mushrooms from various locations. Mushroom JSummer 1990:5-9

Tel G, Çavdar H, Deveci E, Öztürk M, Duru ME, Turkoğlub A (2014) Minerals and metals in mushroom species in Anatolia. Food Addit Contam Part B 7:226-231

UNEP (2013) Mercury-time to act. United Nations Environmental Programme. http://www.unep.org/PDF/PressReleases/Mercury_ TimeToAct.pdf. Accessed Jan 2015

Vetter J, Berta E (1997) Mercury content of some wild edible mushrooms. Z Lebensm Unters For 205:316-320

Zhang H, Yin R-S, Feng X-B, Sommar J, Anderson CWN, Sapkota A, Fu X-W, Larssen T (2013) Atmospheric mercury inputs in montane soils increase with elevation: evidence from mercury isotope signatures. Scientific Reports 3:3322. doi:10.1038/ srep03322

Zhang J, Li T, Yang Y, Liu H, Wang W (2015) Arsenic concentrations and associated health risks in Laccaria mushrooms from Yunnan (SW China). Biol Trace Elem Res 164:261-266

Zhou J, Feng X, Liu H, Zhang H, Fu X, Bao Z, Wang X, Zhang Y (2013) Examination of total mercury inputs by precipitation and litterfall in a remote upland forest of Southwestern China. Atmos Environ 81:364-372

Zielińska M, Danisiewicz-Czupryńska D, Falandysz J (2008) Bionagromadzanie rtęci przez owocniki lakówki ametystowej ( $\mathrm{Lac}$ caria amethystina) [Bioaccumulation of mercury in Amethyst Deceiver (Laccaria amethystina) fruiting bodies]. Bromat Chem Toksykol 3:460-463 